\title{
Civil Law Regulation of Investments in the Scientific and Educational Ecosystem of the University
}

\author{
Anna S. Pugacheva $\left.{ }^{1 *[O R C I D} 0000-0002-8070-0482\right]$, \\ Nailya I. Askarova 2[ORCID 0000-0003-0722-5379]
}

\author{
${ }^{1}$ Kazan (Volga region) Federal University, Kazan, Russia \\ ${ }^{2}$ Russian Academy of National Economy and Public Administration under the President of the Russian \\ Federation, Kazan, Russia \\ anna.pugacheva1997@yandex.ru
}

\begin{abstract}
Civil law regulation of investments is associated with an increase in the role of capital investments in the processes of creating new technologies, implementing scientific and educational projects. There are two approaches to the civil legal regulation of investments: object and activity ones. Within the framework of the object approach, the essence of civil law regulation of investments is defined through the category "object of civil law". Within the framework of the activity approach, the essence of civil law regulation of investments is understood through a set of actions for the transfer of an object and through relations associated with the investment of assets. The purpose of the study is to substantiate the effectiveness of the integration of object and activity approaches to the civil legal regulation of investments in the scientific and educational ecosystem of the university. The methodological basis of the study was formed by general and special methods of cognition, which made it possible to give an adequate assessment of the concepts, to determine the essence of civil legal regulation of investments and the scientific and educational ecosystem of the university. The main results of the study are the following: to clarify the content of the scientific and educational ecosystem of the university; to establish dialectical relationships between the civil law regulation of investments and sustainable development of the scientific and educational ecosystem of the university; to describe the civil law regulation of investments in the scientific and educational ecosystem of the university. In the content of the scientific and educational ecosystem, network, participatory, integrative components are highlighted that generate processes of selforganization and self-development, stimulate the commercialization of innovations, help to minimize risks, focus on improving the quality of life of each person, sustainable development of society. The dialectical interrelationships between the civil legal regulation of investments and the sustainable development of the scientific and educational ecosystem provide support for innovative solutions in the field of end-to-end technologies, the organization of digital platforms and new infrastructure facilities for the training of scientific personnel and specialists with professional skills of the 21st century. A comprehensive characteristic of civil law regulation of investments, which includes legal incentives for investment activities, state support for investors, legal restrictions and prohibitions, state control and supervision, provides an increase in the efficiency of forms and methods of public-private partnership in the process of development, examination, implementation of investment projects in the field science and education. The integration of object and activity approaches to the civil legal regulation of investments in the scientific and educational ecosystem of the university focuses on the improvement of intersectoral harmonization of regulatory and legal norms, the optimization of relations between the subjects of investment activity and the development of variable forms of cooperation.
\end{abstract}

Keywords: civil law regulation of investments, investments in education, scientific and educational ecosystem

\section{INTRODUCTION}

Civil law regulation of investments combines the principles, forms and methods of lawmaking, law enforcement, and norms of different industry affiliations [1]. In Russian science, two approaches to civil law regulation of investments have been formed: object and activity ones [2]. 
Within the framework of object approach, the essence of civil law regulation of investments is determined through the category of "object of civil law" (that is, through understanding what they are investing in and through understanding in what they are investing). The theoretical basis of the object approach is the study of investment liabilities; civil law investment structures [3, 4].

The prerequisites for the object approach are legally significant investment classifications enshrined in Russian legislation [5]. The theoretical significance of the object approach is that it allows finding out the legal content of the civil legal regulation of investments, to improve the legal technique of investment.

Within the framework of the activity approach, the essence of civil law regulation of investments is understood through a set of actions for the transfer of an object; and also, through the relationship associated with the investment of assets. The theoretical basis of the activity approach is the study of the essence and content of the investment process and vigorous activity aimed at achieving the goals of investors; mechanisms of legal regulation of investment activities; investment relations arising based on investment contracts and constituting the subject of civil law regulation $[6,7]$.

The prerequisites for the activity approach are the following: legal forms of investment based on the conclusion of investment agreements; legal types and forms of interaction between property and owners associated with property rights and intellectual property [8]. The theoretical significance of the activity approach is that it allows introducing the concept of investment activity as a subject of civil law regulation into scientific circulation.

The efficiency of civil law regulation of investments in the scientific and educational ecosystem of the university will increase under the condition of the integration of the object and activity approaches. Such integration will ensure the harmonization of regulations to increase investor loyalty, protect their rights and legitimate interests, and the investor's freedom to choose the investment object.

The essence of the scientific and educational ecosystem of the university consists in the integration of scientific and educational processes based on the optimization of the infrastructure of relationships, improving the mechanisms of social partnership, mobilizing resources, transferring technologies and competencies to achieve synergistic results that ensure the development of technological and pedagogical innovations, training specialists with professional skills of the $21 \mathrm{st}$ century, improving the network of continuous education, as well as contributing to improving the quality of life of each person, sustainable development of society [9]. Improvement of the scientific and educational ecosystem of universities is included in the strategic objectives of the development of the Russian Federation [10]. Solution of this problem requires investments with long payback periods and high capital intensity. This updated the study of the problems of civil legal regulation of investments in the scientific and educational ecosystem of the university.

The object of research is the civil regulation of investments in the scientific and educational ecosystem of the university. The purpose of the study is to substantiate the effectiveness of the integration of object and activity approaches to civil law regulation of investments in the scientific and educational ecosystem of the university.

\section{MATERIALS AND METHODS}

The methodological basis of the research was formed by general and special methods of cognition. The general methods were historical materialism, generalization and abstraction, analysis and synthesis, induction and deduction, analogy, observation, logical method [11]. The set of general methods made it possible to establish dialectical relationships between the civil law regulation of investments and the sustainable development of the scientific and educational ecosystem of the university.

Special methods constituted the technical-legal and intersectoral method [12]. Special methods made it possible to give an adequate assessment of the concepts, to find out the content of the scientific and educational ecosystem of the university; give a comprehensive description of the civil law regulation of investments in the scientific and educational ecosystem of the university and substantiate the effectiveness of the integration of object and activity approaches.

The legal basis for the study is the following: Federal Law of February 25, 1999 No. 39-FZ "On investment activities in the Russian Federation carried out in the form of capital investments"; Federal Law of July 9, 1999 No. 160-FZ "On Foreign Investments in the Russian Federation" [13, 14]. 


\section{RESULTS}

\subsection{The content of the scientific and educational ecosystem of the university}

The main results of the study are to clarify the content of the scientific and educational ecosystem of the university; the establishment of dialectical relationships between the civil law regulation of investments and the sustainable development of the scientific and educational ecosystem of the university; a comprehensive description of the civil law regulation of investments in the scientific and educational ecosystem of the university.

The technological revolution, the digitalization of society, the search for new ways of organizing socio-economic reality have led to a new look at education as a tool for sustainable development and general well-being, including conscious goaloriented activities based on constant productive interaction and the expansion of tools for accumulating human capital [15].

The content of the scientific and educational ecosystem of the university consists of the following components: 1) network, connecting scientific and educational structures on different logical grounds for mobilizing resources, transfer of technologies and competencies, development and commercialization of technological and pedagogical innovations, successful completion of multi-projects, improvement of the lifelong education network; 2) participatory, combining formal and informal institutions to optimize the infrastructure of relationships, improve the mechanisms of social partnership, effectively select leading indicators and organize a rating assessment of structural units and teachers, increase the number of research and development work and the number of startups, as well as obtain new licenses for educational activities; 3) integrative, ensuring the systemic integrity of education, science and production for training specialists with professional skills of the 21 st century, increasing the competitiveness of the university, as well as creating tangible (property) and intangible (patents, licenses, software products, technologies) assets and increasing their profitability.

The content of the scientific and educational ecosystem of the university generates processes of self-organization and self-development, stimulates the commercialization of innovations, helps to minimize risks, focuses on improving the quality of life of each person, sustainable development of society.

\subsection{Dialectical interconnections of civil legal regulation of investments and sustainable development of the scientific and educational ecosystem of the university}

Civil law regulation of investments is associated with an increase in the role of capital investments in the creation of new technologies, the implementation of scientific and educational projects [16].

The scientific and educational ecosystem is a constantly evolving component of the university's activities, ensuring the disclosure of the individual and collective potential of each participant, providing the opportunity to exercise the right to education throughout life, contributing to the sustainable development of society and improving the quality of life based on the conscious consolidation of the subjects of relations in the field of education, subjects of the labor market and civil society institutions, adaptation of educational resources and technologies to the requirements of the digital economy and the needs of students.

Sustainable development of the scientific and educational ecosystem expands the understanding of education management, focuses on strengthening the relationship and interdependence of science and education in the process of transfer of technologies and competencies, commercialization of innovations for the development of scientific and technical, socio-cultural, artistic creativity, promotion of knowledge through scientific research and dissemination of their results, as well as ensuring equal access to personalized, collaborative, networked lifelong learning.

The dialectical interrelationships between the civil legal regulation of investments and the sustainable development of the scientific and educational ecosystem of the university have been established: 1) the efficiency of civil legal regulation of investments increases subject to the integration of scientific and educational processes, the improvement of social partnership mechanisms, the effective selection of leading indicators and the organization of rating assessment of structural units and faculty [17]; 2) the effectiveness of the civil legal regulation of investments increases under the condition of the development and commercialization of technological and pedagogical innovations, the successful completion of multi-projects, the creation of tangible and intangible assets and an increase in their profitability [18]; 3) the actualization of civil legal regulation of investments increases subject to the improvement of the network of continuous education, training of specialists with professional 
skills of the 21st century [19]; 4) the importance of civil legal regulation of investments increases subject to the transfer of technologies and competencies, an increase in the number of research and development works, the number of startups, as well as obtaining new licenses for educational activities [20].

The established relationships ensure the improvement of cooperation between the subjects of educational relations, the implementation of advanced training of scientific personnel and specialists with professional skills of the 21 st century; as well as support for innovative solutions in the field of end-to-end technologies, organization of digital platforms and new infrastructure facilities [21].

\subsection{Comprehensive characteristics of the civil legal regulation of investments in the scientific and educational ecosystem of the university}

Investments in the scientific and educational ecosystem of the university are characterized by: 1) a profitable investment, provided that the amount of investments is preserved in value terms and the subsequent receipt of profit and (or) the achievement of another useful effect; 2) the expected return, subject to the implementation of comprehensive control and accounting for the investment of funds by a qualified and (or) institutional investor on a reimbursable basis; 3) investment risk, subject to the depreciation of investments and (or) loss of income from them; 4) a contractual form, subject to a variety of types of investment activities that are the subject of civil or public law regulation; 5) a sequence, including organizational, investment, entrepreneurial stages, subject to the emergence, change, termination of investment legal relations [22].

A comprehensive description of the civil law regulation of investments in the scientific and educational ecosystem of the university includes: 1) legal incentives for investment activities (improvement of taxation; revaluation of fixed assets in accordance with inflation rates); 2) state support for investors (preferential conditions for the use of natural resources; expanding the use of sources of financing for the construction of infrastructure facilities; expanding the possibility of using collateral for lending; developing financial leasing; creating an opportunity to form investment funds; providing state guarantees for investment projects on a competitive basis); 3) legal restrictions, prohibitions (examination of investment projects; protection from the supply of obsolete and materialintensive, energy-intensive and non-high-tech technologies, equipment, materials); 4) state control and supervision (regular rating and publication of ratings of subjects of investment activities; taking measures to terminate and prevent antimonopoly legislation).

\section{DISCUSSION}

The object and activity approaches to the civil legal regulation of investments in the scientific and educational ecosystem of the university do not contradict each other. They are dialectically interconnected.

The object approach focuses on identifying the essential characteristics of investments in the scientific and educational ecosystem of the university, which reflect the object of civil rights (money, equipment, technology, software) invested in scientific and educational projects to make a profit and (or) achieve another useful effect [23].

The activity approach focuses on the establishment of dialectical relationships between the civil law regulation of investments and the sustainable development of the scientific and educational ecosystem of the university, which reflect the essence of investment as a process of investing an object of civil rights as investments to support fundamental and applied research on the priorities of scientific and technological development and the creation of new competitive technologies and products and their commercialization, as well as training personnel capable of solving scientific and technological problems in the interests of the development of science, technology, education, the Russian economy [24].

\section{CONCLUSION}

The integration of the object and activity approaches focuses on the complex characteristics of the civil law regulation of investments in the scientific and educational ecosystem of the university, which ensures the development of conditions for investment activity; improving crosssectoral harmonization of regulatory and legal norms and increasing the investment attractiveness of scientific and educational projects; the effectiveness of public-private partnership in the process of development, examination, implementation of investment projects $[25,26]$.

The practical significance of the study lies in the fact that the content of the scientific and educational 
ecosystem of the university has been clarified, which makes it possible to optimize the civil regulation of relations between the subjects of investment activity and to develop variable forms of cooperation (consortia, clusters, corporations, scientific and educational centers, strategic alliances, cartels, patent pools).

\section{AUTHORS' CONTRIBUTIONS}

The authors made an equal contribution to the study: collection and analysis of material; definition of goals and objectives, research methods; formulation and scientific substantiation of conclusions, registration of key research results in the form of an article.

\section{REFERENCES}

[1] A. Pugacheva, M. Hakimullin, M. Badrutdinov, S. Kashina, A. Lunev, "Civil law regulation of investments in the digital infrastructure of the construction industry", In E3S Web of Conferences, 2021, vol. 274, p. 06004. DOI: $10.1051 / \mathrm{e} 3$ sconf/202127406004

[2] I.I. Shuvalov, "Civil law provisions to regulate investment activities", The Rule-of-Law State: Theory and Practice, 2020, vol. 3(61), pp. 9099. (In Russ.). DOI: 10.33184/pravgos2020.3.10

[3] O. Minkeev, S. Sharonov, "Legal regulation of investment activity in the republic of Kalmykia in the context of the digital economy development: the civil aspect", SHS Web of Conferences, 2021, vol. 109, p. 01022. DOI: $10.1051 /$ shsconf/202110901022

[4] N. Hladynets, N. Ryashko, "Theoretical framework for investment and innovation processes of territorial development", Economic Scope, 2021, Vol. 169, pp. 56-60. DOI: $10.32782 / 2224-6282 / 169-10$

[5] K. Belikova, N. Badaeva, M. Akhmadova, N. Khoshobina, "Specifics of the mechanism of civil regulation of investment relations: Russia's results", Journal of Advanced Research in Law and Economics, 2018, vol. 9(3), pp. 894-904. DOI: $10.14505 /$ jarle.v93(33).12

[6] O.V. Markova, E. Ye. Listopad, A.V. Shelygov, A.G. Fedorov, I.V. Kiselevich, "Economic and legal aspects of the innovative activity of enterprises in the context of the digital economy", Nexo Revista Científica, 2021, vol. 34(02), pp. 964-972. DOI: 10.5377/nexo.v34i02.11623

[7] A.N. Lunev, N.B. Pugachova, L.Z. Stukolova, "Socially oriented regional economic space as an instrument in managing the development of service sector", Actual Problems of Economics, 2014, vol. 155 (5), pp. 247-250. (In Ukr.).

[8] I. Levchenko, O. Dmytriieva, I. Shevchenko, O. Solodovnik, I. Britchenko, V. Kruhlov, N. Avanesova, O. Kudryavtseva, "Development of a Method for Selected Financing of scientific And Educational institutions Through targeted Capital Investment in the Development of innovative Technologies", Eastern-European Journal of Enterprise Technologies, 2021, vol. 3(13-111), pp. 55-62. DOI: 10.15587/17294061.2021.235930

[9] A. Padilla-Meléndez, E. Fuster, N. Lockett, A.R. del-Aguila-Obra, "Knowledge spillovers, knowledge filters and entrepreneurial university ecosystems. Emerging role of universityfocused venture capital firms", Knowledge Management Research and Practice, 2021, vol. 19(2), pp. 1-12. DOI: $10.1080 / 14778238.2020 .1740626$

[10] V.A. Svechnikov, "Current Issues of the Legal Regulation of Investment Activities in the Russian Federation", Economics. Law. Society, 2019, vol. 1(17), pp. 82-87 (In Russ.).

[11]O.A. Kuznetsova, "Methods of scientific research in Civil dissertations", Perm University Herald. Juridical Sciences, 2014, vol. 4(26), pp. 254-270. (In Russ.).

[12]E.G. Komissarova, "Parameters of the methodology of jurisprudence in their functional value (on the example of Civil Law)", Methodological Problems of the Civil Law Researches, 2021, vol. 3(3), pp. 50-75. (In Russ.). DOI: 10.33397/2619-0559-2021-3-3-5075

[13]Federal Law of 25.02.1999 No. 39-FZ (as revised on 08.12.2020) "On investment activities in the Russian Federation carried out in the form of capital investments", 2020. (In Russ.). Retrieved from https://docs.cntd.ru/document/901727484

[14]Federal Law of 09.07.1999 No. 160-FZ (as revised on 02.07.2021) "On foreign investments in the Russian Federation”, 2021. (In Russ.). Retrieved from 
[15]M. Usak, M.Y. Hsieh, Y.-K. Chan, "A concretizing research on making highereducation sustainability count", Sustainability (Switzerland), 2021, vol. 13(5), p. 2724. DOI: $10.3390 / \mathrm{su} 13052724$

[16] O.A. Eremchenko, F.A. Kurakov, "Investment Strategies and Tools of Foreign and Russian Universities", The Economics of Science, 2021, vol. 7(2), pp. 88-110. (In Russ.). DOI: 10.22394/2410-132x-2020-7-2-88-110

[17] N.B. Pugacheva, S.G. Kashina, T.V. Kirillova, I.G. Ovchinnikova, N.K. Kudyashev, A.N. Lunev, O.A. Pavlova, A.S. Valeyev, "The Mechanism of State-Public Management of Vocational Education in the Region", International Review of Management and Marketing, 2016, vol. 6(2), pp. 6-11.

[18]D. Iacobucci, A. Micozzi, A. Piccaluga, "An empirical analysis of the relationship between university investments in Technology Transfer Offices and academic spin-offs", R \& D Management, 2021, vol. 51(1), pp. 3-23. DOI: 10.1111/radm.12434

[19] A.N. Lunev, N.B. Pugacheva, L.Z. Stukolova, "Development strategies for professional educational services under the increasing autonomy of territories within the federal state", Actual Problems of Economics, 2014, vol. 160(1), pp. 215-220. (In Russ.).

[20] A.N. Lunev, R.S. Safin, E.A. Korchagin, D.K. Sharafutdinov, T.V. Suchkova, L.V. Kurzaeva, S.R. Nikishina, N.A. Kuznetsova, "The Mechanism of Industrial Educational Clusters Creation as Managerial Entities of Vocational Education", International Review of Management and Marketing, 2016, vol. 6(2), pp. 166-171.

[21] G.I. Loayza Acosta, N.A. Bernardo Reyes, M.E. Calle Arancibia, "Returns to Investment in
University Education - Economics Career at Continental University", Research in World Economy, 2021, vol. 12(1), pp. 166. DOI: 10.5430/rwe.v12n1p166

[22]L. Liu, L. Gao, "Financing university sustainability initiatives in China: actors and processes", International Journal of Sustainability in Higher Education, 2021, vol. 22(1), pp. 44-58. DOI: 10.1108/IJSHE-112019-0333

[23] V.G. Ivanov, S.V. Barabanova, R.V. Shagieva, N.M. Chikisheva, A.N. Lunev, N.V. Volkova, K.R. Nabiullina, E.V. Spirina, "The Essence and Content of State Regulation of Services Development in Conditions of Increasing Autonomy of Federal State Entities", International Review of Management and Marketing, 2016, vol. 6(2), pp. 149-154.

[24]I. Terentyeva, A. Lunev, S. Kashina, L. Sadrieva, I. Korolyuk, N. Pugacheva, "The virtual construction site: Knowledge management in virtual environments", International Journal of Emerging Technologies in Learning, 2020, vol. 15(13), pp. 81-95. DOI: 10.3991/ijet.v15i13.14655

[25]N. Pugacheva, T. Kirillova, O. Kirillova, A. Luchinina, I. Korolyuk, A. Lunev, "Digital Paradigm in Educational Management: The Case of Construction Education Based on Emerging Technologies", International Journal of Emerging Technologies in Learning, 2020, vol. 15(13), pp. 96-115. DOI: 10.3991/ijet.v15i13.14663

[26]C. Mascarenhas, C.S. Marques, J.J. Ferreira, A.R. Galvão, "The influence of research and innovation strategies for smart specialization (Ris3) on university-industry collaboration", Journal of Open Innovation: Technology, Market, and Complexity, 2021, vol. 7(1), p. 82. DOI: $10.3390 / J O I T M C 7010082$ 